\title{
Targeted lung cancer therapy: preparation and optimization of transferrin-decorated nanostructured lipid carriers as novel nanomedicine for co-delivery of anticancer drugs and DNA
}

This article was published in the following Dove Press journal:

International Journal of Nanomedicine

II February 2015

Number of times this article has been viewed

\author{
Zhenyu Shao' \\ jingyu Shao ${ }^{2}$ \\ Bingxu Tan' \\ Shanghui Guan' \\ Zhulong Liu' \\ Zengjun Zhao' \\ Fangfang $\mathrm{He}^{\prime}$ \\ Jian Zhao ${ }^{3}$ \\ 'Department of Radiotherapy, Cancer \\ Centre, Qilu Hospital, Shandong \\ University, Ji'nan, Shandong, People's \\ Republic of China; ${ }^{2}$ Affiliated Hospital \\ of Northwest Institute of Mechanical \\ and Electrical Engineering, Xianyang, \\ Shaanxi, People's Republic of China; \\ ${ }^{3}$ Department of Thoracic Surgery, \\ Qilu Hospital, Shandong University, \\ Ji'nan, Shandong, People's Republic \\ of China
}

Purpose: Nanostructured lipid carriers (NLC) represent an improved generation of lipid nanoparticles. They have specific nanostructures to accommodate drugs/genes, and thus achieve higher loading capacity. The aim of this study was to develop transferrin (Tf)-decorated NLC as multifunctional nanomedicine for co-delivery of paclitaxel (PTX) and enhanced green fluorescence protein plasmid.

Methods: Firstly, Tf-conjugated ligands were synthesized. Secondly, PTX- and DNA-loaded NLC (PTX-DNA-NLC) was prepared. Finally, Tf-containing ligands were used for the surface decoration of NLC. Their average size, zeta potential, drug, and gene loading were evaluated. Human non-small cell lung carcinoma cell line (NCl-H460 cells) was used for the testing of in vitro transfection efficiency, and in vivo transfection efficiency of NLC was evaluated on mice bearing NCl-H460 cells.

Results: Tf-decorated PTX and DNA co-encapsulated NLC (Tf-PTX-DNA-NLC) were nanosized particles with positive zeta potential. Tf-PTX-DNA-NLC displayed low cytotoxicity, high gene transfection efficiency, and enhanced antitumor activity in vitro and in vivo.

Conclusion: The results demonstrated that Tf-PTX-DNA-NLC can achieve impressive antitumor activity and gene transfection efficiency. Tf decoration also enhanced the active targeting ability of the carriers to NCl-H460 cells. The novel drug and gene delivery system offers a promising strategy for the treatment of lung cancer.

Keywords: co-delivery, nanostructured lipid carriers, transferrin decoration, active targeting systems, paclitaxel

\section{Introduction}

Lung cancer is one of the most lethal cancers worldwide and the second most common cancer in both men and women. ${ }^{1}$ Current therapies for lung cancer treatment include chemotherapy, radiotherapy, and surgery. Although chemotherapy continues to play an important role in the treatment of lung cancer, multidrug resistance and severe adverse effects on normal tissues are major causes for failures in clinical cancer chemotherapy. ${ }^{2-4}$ Therefore, active targeting by nanocarriers and co-delivering or combination therapy are highlighted in recent perspectives. ${ }^{5-8}$

Nanostructured lipid carriers (NLC) were introduced in the late 1990s. NLC, composed of a mixture of a solid and liquid lipid, which is solid at room and body temperature, are second-generation solid-lipid-based colloidal carriers
Correspondence: Jian Zhao

Department of Thoracic Surgery,

Qilu Hospital, Shandong University,

44 Wenhuaxi Road, Jinan 250012,

Shandong Province, People's

Republic of China

Email shaozhenyusdu@I63.com 
with improved stability and drug encapsulation ability. ${ }^{9}$ In contrast to the other colloidal carrier schemes, such as liposomes, ${ }^{10}$ micro- and nanoemulsions, ${ }^{11}$ nanocapsules, ${ }^{12}$ nanosponges, ${ }^{13}$ and polymeric nanoparticles,${ }^{14}$ the advantages of NLC are the following: 1) controlled drug release; 2) high drug loading efficacy; 3) an increase in chemical stability of the incorporated drugs; and 4) the possibility of large-scale production. ${ }^{15,16}$ Furthermore, cellular uptake tests have demonstrated the faster internalization of NLC into cancer cells. ${ }^{17}$

The effectiveness of NLC could be further improved by actively targeting tumors with ligands coated on the surface of NLC; these ligand-coated NLC could be taken through a receptor-mediated endocytic pathway. ${ }^{18-20}$ Transferrin (Tf) has been used as a cancer-targeting agent in multiple delivery systems since the transferring receptor is over-expressed in many types of cancer cells. ${ }^{21}$ Such expression may be up to 100 -fold greater than average expression in normal cells. ${ }^{22}$ Polyethylene glycol-phosphatidylethanolamine (PEG-PE) conjugates with various PEG lengths and terminal-targeted moieties can provide extremely stable and actively targeted vectors that spontaneously accumulate at specific sites..$^{23,24}$ Therefore, Tf was conjugated with PEG-PE to form Tf-PEG-PE. Tf-PEG-PE was used as a ligand to decorate NLC to create a multifunctional nanomedicine.

The co-delivery of gene and chemotherapy drugs is another hot topic in the field of combination therapy. ${ }^{25,26}$ Nanocarriers decorated with folic acid, hyaluronic acid, biotin, and $\mathrm{Tf}$ are designed to co-deliver gene drugs and chemotherapy drugs. Gene drugs generally target antiapoptotic genes or multidrug resistance-related genes, and can enhance the effects of cytotoxic drugs such as doxorubicin and docetaxel. ${ }^{27}$

Paclitaxel (PTX), a taxane obtained from Pacific yew (Taxus brevifolia), is a microtubule stabilizer. PTX has been used in a number of malignancies including breast cancer, non-small cell lung cancer, and advanced ovarian carcinoma. ${ }^{28,29}$ Because of its low solubility (about $0.3 \mu \mathrm{g} / \mathrm{mL}$ ), the commercial formulation Taxol ${ }^{\circledR}$ contains Cremophor ${ }^{\circledR}$ EL and ethanol with a volume ratio of 50:50. However, the high amount of Cremophor EL results in significant side effects, which limits the clinical application of PTX. Although various approaches were employed to enhance the aqueous solubility of PTX by utilizing liposomes, micelles, nanoparticles, and liquid crystalline nanoparticles, ${ }^{30}$ each approach suffers from known limitations. Still, few publications have reported on the co-delivery of genes and PTX for use as a type of lung cancer therapy.
In the current study, Tf-PEG-PE-decorated NLC, a novel nanomedicine for the co-delivery of PTX and DNA, were prepared and examined in mice bearing $\mathrm{NCl}$ H460 cells. Plasmid-enhanced green fluorescent protein was used as the model DNA. This system was expected to: 1) achieve stable PTX- and DNA-loading capacity; 2) be recognized by Tf receptors over NCl-H460 cells; 3) be internalized via receptor-mediated endocytosis; and finally 4) achieve co-delivery of both PTX and DNA therapeutic effects.

\section{Materials and methods Materials}

Aldehyde PEG Aldehyde, CHO-PEG-CHO (with average molecular weights of 2, 5, and $10 \mathrm{kDa}$ ) was purchased from Taiyuan Pegchem Technology Co, Ltd (Shanxi, People's Republic of China); human Tf (iron-free), phosphatidylethanolamine (PE), Roswell Park Memorial Institute (RPMI) 1640, oleic acid, and Tween ${ }^{\circledR} 80$ were purchased from Sigma Aldrich Co, Ltd (St Louis, MO, USA). N-[1-(2,3-dioleyloxy) propyl]-N,N,N-trimethyl-ammonium chloride (DOTMA) was purchased from TCI (Shanghai) Development Co., Ltd. (People's Republic of China). Glyceryl monostearate was purchased from Shanghai Chineway Pharmaceutical Technology Co, Ltd (Shanghai, People's Republic of China). Injectable soya lecithin was obtained from Shanghai Taiwei Pharmaceutical Co, Ltd (Shanghai, People's Republic of China). Paclitaxel was provided by Zhejiang Hisun Pharmaceutical Co, Ltd (Taizhou Zhejiang, People's Republic of China). PTX injection (Taxol) was produced by Bristol-Myers Squibb Company (New York, NY, USA). Plasmid-enhanced green fluorescent protein-N1 was provided by Shandong University (Shandong, People's Republic of China). Quant-iT'TM PicoGreen ${ }^{\circledR}$ double-strand (ds) DNA quantitation reagent was obtained from Thermo Fisher Scientific (Waltham, MA, USA). Fetal bovine serum was the product of Thermo Fisher Scientific. All other reagents used were of the highest quality commercially available. NCl-H460 human non-small cell lung carcinoma cells were obtained from the American Type Culture Collection (ATCC), Manassas, VA, USA.

\section{Animals}

Male BALB/c mice (18-22 g weight) were purchased from the Medical Animal Test Center of Shandong Province (Shandong, People's Republic of China). All animal experiments complied with the requirements of the National Act on the Use of Experimental Animals (People's Republic of China). 


\section{Preparation of PTX- and DNA-loaded NLC}

The PTX- and DNA-loaded NLC (PTX-DNA-NLC) formulation was prepared by the microemulsion technique. ${ }^{30} \mathrm{~A}$ mixture of glyceryl monostearate, oleic acid, plus soya lecithin $(1: 1: 1, \mathrm{w} / \mathrm{w} / \mathrm{w})$ and PTX $(75 \mathrm{mg})$ was heated; then, $300 \mu \mathrm{L}$ of distilled water was added under magnetic stirring to form a lipid dispersion. A cold water dispersion was prepared by dissolving DNA, DOTMA, and Tween-80 in $50 \mathrm{~mL}$ distilled water. This aqueous solution was then stirred and cooled to $2{ }^{\circ} \mathrm{C}-8^{\circ} \mathrm{C}$. This hot lipid dispersion was dispersed into the cold water dispersion under vigorous stirring $(13,000 \mathrm{rpm}$ for 10 minutes; IKA T 25 Ultra-Turrax ${ }^{\circledR}$,Thermo Fisher Scientific) to form the PTX-DNA-NLC dispersion. Blank NLC was also prepared as described above in this section, without adding PTX and DNA.

\section{Preparation and characterization of Tf-PEG-PE}

Tf-PEG was synthesized using three kinds of CHO-PEG-CHO (molecular weights, 2, 5, and $10 \mathrm{kDa}$ ) reacted with $\mathrm{Tf}$ in the presence of $30 \mathrm{mM}$ sodium cyanoborohydride $\left(\mathrm{NaCNBH}_{3}\right)$ in $100 \mathrm{mM}$ acetate buffer at $\mathrm{pH}$ 5.0. Reaction mixtures were separated by gel-filtration chromatography using a Sephacryl S-200 column. Tf-PEG fractions were then collected and concentrated using an Amicon Ultra-4 centrifugal filter. TfPEG-CHO and PE were reacted in the presence of 1-ethyl-3 -[3-dimethylaminopropyl]carbodiimide hydrochloride (EDC $\mathrm{HCl}$ ) (two equivalents of $\mathrm{PE}$ ) and triethylamine (TEA; one equivalent of EDC $\mathrm{HCl}$ ) in dimethyl sulfoxide (DMSO). The mixture was centrifuged at $10,000 \mathrm{rpm}$ for 30 minutes at $4{ }^{\circ} \mathrm{C}$, and then resuspended in phosphate-buffered saline (PBS; $\mathrm{pH}$ 7.4). The structures of Tf-PEG-PE with different PEG molecular weights were confirmed by infrared and proton nuclear magnetic resonance ( ${ }^{1} \mathrm{H}$ NMR) spectroscopy.

\section{Preparation of Tf-decorated PTX and DNA co-encapsulated NLC}

Tf-decorated PTX and DNA co-encapsulated NLC (Tf-PTXDNA-NLC) was prepared by electrostatic attraction and lipophilic interaction. Briefly, $1 \mathrm{~mL}$ PTX-DNA-NLC dispersion was slowly added under stirring (400 rpm) to the Tf-PEG-PE PBS solution. ${ }^{31}$ Subsequently, free Tf-PEG-PE was removed from Tf-decorated NLC by gel-filtration chromatography, using a Sephadex ${ }^{\circledR}$ G-50 column. The obtained complexes were resuspended in Milli-Q water and filtered through a membrane with $0.45 \mu \mathrm{m}$ pore size to obtain Tf-PTX-DNA-NLC (Figure 1). Preparations of Tf-PEG-PE

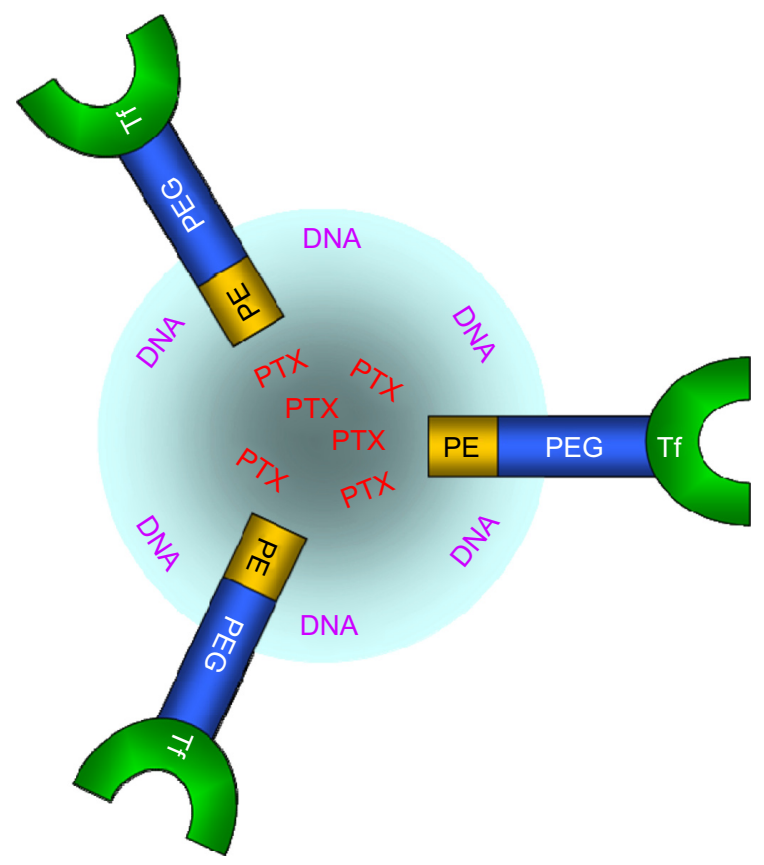

Figure I Schematic diagram of Tf-PTX-DNA-NLC.

Notes: Tf-PTX-DNA-NLC was prepared, firstly, by the formation of PTX-DNANLC, and then, Tf-PEG-PE was prepared and was placed onto the surface of PTXDNA-NLC to obtain Tf-PTX-DNA-NLC.

Abbreviations: Tf-PTX-DNA-NLC, transferrin-decorated paclitaxel and deoxyribonucleic acid co-encapsulated nanostructured lipid carriers; PTX-DNA-NLC, paclitaxel- and deoxyribonucleic acid-loaded nanostructured lipid carriers; Tf-PEG$\mathrm{PE}$, transferrin-conjugated polyethylene glycol-phosphatidylethanolamine.

with different molecular weights of PEG were investigated separately. Blank Tf-NLC was also prepared as described above in this section, without adding PTX and DNA.

\section{Preparation of Lipofectamine ${ }^{\circledR}$-DNA complexes}

For assessing the gene transfection efficacy of Tf-PTX-DNANLC and PTX-DNA-NLC, the Lipofectamine(Lipo)-DNA complexes were prepared by the following method: ${ }^{32}$ DNA and Lipofectamine $2000(1: 2, \mathrm{w} / \mathrm{w})$ were mixed for 30 seconds using a vortex mixer. Then, the DNA loaded liposomes were obtained by incubating the mixture for 30 minutes.

\section{Characterization of PTX-DNA-NLC and Tf-PTX-DNA-NLC}

The surface morphologies of both PTX-DNA-NLC and TfPTX-DNA-NLC were examined by transmission electronic microscopy (TEM). The average particle size, polydispersity index (PDI) and zeta potential of PTX-DNA-NLC and TfPTX-DNA-NLC were determined by laser light scattering (3000 SH; Malvern Instruments Ltd, Malvern, UK).

The DNA-loading ability (DL) of PTX-DNA-NLC was determined by the PicoGreen-fluorometry method. ${ }^{33}$ 
The DNA was isolated from PTX-DNA-NLC by centrifugation at $10,000 \times g$ for 20 minutes at $4^{\circ} \mathrm{C}$. The DNA content in the supernatant was measured. DL was calculated according to the linear calibration curve of DNA:

$$
\operatorname{DL}(\%)=\frac{\mathrm{W}_{\text {total-DNA }}-\mathrm{W}_{\text {free-DNA }}}{\mathrm{W}_{\text {total DNA }}} \times 100
$$

$\mathrm{W}_{\text {total-DNA }}$ is the weight of DNA added when preparing PTXDNA-NLC; $\mathrm{W}_{\text {free-DNA }}$ is the weight of the DNA measured in the supernatant.

The PTX encapsulation efficiency (EE) of PTX-DNANLC was determined by a subtraction method. Briefly, the obtained PTX-DNA-NLC was precipitated by the $\mathrm{pH}$ adjustment. After the centrifugation, the NLC precipitate was obtained, and the drug content in the supernatant was measured by high-performance liquid chromatography (HPLC; 1260 Series; Agilent Technologies, Santa Clara, CA,USA). ${ }^{34,35}$ Chromatographic separations were carried out using the Inertsil ${ }^{\circledR}$ ODS-3V $(250 \mathrm{~mm} \times 4.6 \mathrm{~mm})$. Mobile phase consisted of a mixture of acetonitrile and water (50:50, $\mathrm{v} / \mathrm{v})$. Flow rate was kept at $1.0 \mathrm{~mL} /$ minute, and the system was maintained at $35^{\circ} \mathrm{C}$; the detection was carried out at $\lambda=227 \mathrm{~nm}$. Injection volume was $20 \mu \mathrm{L}$. Equation 2 was used to calculate EE:

$$
\mathrm{EE}(\%)=\frac{\mathrm{W}_{\text {total-PTX }}-\mathrm{W}_{\text {free-PTX }}}{\mathrm{W}_{\text {total }-\mathrm{PTX}}} \times 100
$$

$\mathrm{W}_{\text {total-PTX }}$ is the weight of PTX added when preparing PTXDNA-NLC; $\mathrm{W}_{\text {free-PTX }}$ is the weight of the PTX measured in the supernatant. The DL and EE of Tf-PTX-DNA-NLC were determined by the same method as PTX-DNA-NLC mentioned above in this section.

\section{In vitro drug release assay}

The amounts of PTX released from Tf-PTX-DNA-NLC, PTX-DNA-NLC, and Taxol were measured by the dialysis method. Tf-PTX-DNA-NLC (5 mL), PTX-DNA-NLC (diluted to the concentration of $0.3 \mathrm{mg} / \mathrm{mL}$ ), and Taxol $(0.3 \mathrm{mg} / \mathrm{mL})$ were placed in the dialysis bag separately. Then, the bag was incubated with $50 \mathrm{~mL}$ release medium (0.1\% Tween 80 in PBS, $\mathrm{pH} 7.4)$. The medium (1 mL) was collected at predetermined time points and replaced with $50 \mathrm{~mL}$ of fresh medium. The concentrations of released PTX were determined by the HPLC method mentioned in the "Characterization of PTX-DNA-NLC and Tf-PTX-DNANLC" section above.

\section{In vitro cytotoxicity studies}

The cytotoxicity of Tf-PTX-DNA-NLC and PTX-DNA-NLC against NCl-H460 cells was measured by 3-(4,5-dimethylthiazol-2-yl)-2,5-diphenyltetrazolium bromide (MTT) assay. Cells were seeded in a 48-well plate at a seeding density of $10^{4}$ cells per well, then incubated in RPMI 1640 medium supplemented with $10 \%$ fetal bovine serum and antibiotics under $5 \% \mathrm{CO}_{2}$ at $37^{\circ} \mathrm{C}$ for 24 hours. The medium was then replaced with various doses of Tf-PTX-DNA-NLC and PTXDNA-NLC. Culture medium was used as a blank control. After 48 hours of incubation, MTT solution $(5 \mathrm{mg} / \mathrm{mL})$ was added to each well, and the cells were incubated for another 4 hours. DMSO (200 mL) was added to each well to dissolve the MTT formazan crystals. The absorption of formazan product was measured using a microplate reader (Model 680; Bio-Rad Laboratories Inc., Hercules, CA, USA) at $570 \mathrm{~nm}$.

\section{In vivo antitumor efficacy}

Male BALB/c mice were inoculated subcutaneously in the left armpit with $100 \mu \mathrm{L} \mathrm{NCl-H460} \mathrm{cells}\left(2 \times 10^{6}\right.$ cells/ $\left.\mu \mathrm{L}\right)$ suspended in PBS. Then, tumor bearing mice were randomized into five groups (six mice per group). Tf-PTX-DNA-NLC (1 mL containing $1.25 \mathrm{mg} / \mathrm{mL}$ PTX), PTX-DNA-NLC (containing $1.3 \mathrm{mg} / \mathrm{mL}$ PTX), Taxol, and $0.9 \%$ sodium chloride solution (containing saline, as blank control) were injected into the mice via the tail vein every other day for 14 days.

The volumes of the solid tumor were measured with a digital caliper every 2 days, and were calculated according to Equation $3:^{36}$

$$
\mathrm{V}\left(\mathrm{mm}^{3}\right)=\frac{\mathrm{L} \times \mathrm{W}^{2}}{2}
$$

$\mathrm{L}$ and $\mathrm{W}$ represent the largest diameter and the smallest tumor diameter, respectively.

The antitumor efficacy of each formulation was evaluated by tumor inhibition rate (TIR), which was calculated using the following equation: ${ }^{37}$

$$
\operatorname{TIR}(\%)=\frac{\mathrm{W}_{\text {control }}-\mathrm{W}_{\text {sample }}}{\mathrm{W}_{\text {control }}} \times 100
$$

$\mathrm{W}_{\text {sample }}$ and $\mathrm{W}_{\text {control }}$ represent the tumor weight of the samples and control group, respectively.

\section{In vitro transfection analysis}

The NCl-H460 cells were seeded into 48-well plates at a density of $1 \times 10^{5}$ cells/well and transfected the next day. Prior to transfection, the media were replaced with $300 \mu \mathrm{L}$ transfection media containing Tf-PTX-DNA-NLC, PTX-DNA-NLC, 
Lipo-DNA, naked DNA solution, or blank NLC. The original incubation medium was replaced with $1 \mathrm{~mL}$ of complete medium after incubation at $37^{\circ} \mathrm{C}$ for 4 hours under a $5 \%$ $\mathrm{CO}_{2}$ atmosphere. The cells were incubated and studied until 72 hours post-transfection. The transfection efficiency of the fluorescent cells was quantitated using flow cytometry. Before quantitative detection, cells were washed with cold saline twice and detached with trypsin/ethylenediaminetetraacetic acid (EDTA). Then, the supernatant used for the luciferase assay was removed, resuspended with PBS, and added into the flow cytometer to quantitate the amount of cells that were successfully transfected.

\section{In vivo gene transfection analysis}

The BALB/c mice model for lung cancer was constructed using the method described in the "In vivo antitumor efficacy" section. Then, tumor-bearing mice received an intravenous injection of Tf-PTX-DNA-NLC, PTX-DNA-NLC, LipoDNA, naked DNA solution, or blank NLC $(300 \mu \mathrm{L}$ per injection). After 36 hours (or 72 hours, in some cases), mice were sacrificed with cervical dislocation, and their tumor tissues were taken and washed with cold saline twice. The tissues were homogenized with lysis buffer $\left(0.05 \%\right.$ Triton $^{\mathrm{TM}} \mathrm{X}-100$, $2 \mathrm{mM}$ EDTA, and 0.1 M Tris-HCl, $\mathrm{pH} 7.8) .{ }^{38}$ After several cycles of freezing and thawing, the homogenates were centrifuged at $10,000 \times g$ for 5 minutes to obtain the cells. Cells were cultured by the method described in the "In vitro cytotoxicity studies" section. The transfection efficiency of the fluorescent cells was quantitated using flow cytometry. Before quantitative detection, cells were washed with cold saline twice and detached with trypsin/EDTA. Then, the supernatant used for the luciferase assay was removed, resuspended with PBS, and added into the flow cytometer to quantitate the amount of cells that were successfully transfected.

\section{Statistical analysis}

All experiments were performed in triplicate. Data were expressed as the mean \pm standard deviation (SD). Statistical analysis was performed using one-way analysis of variance (ANOVA), followed by Tukey-Kramer multiple comparison test. Values were considered statistically significant at $P<0.05$.

\section{Results and discussion Characterization of Tf-PEG-PE ligands}

The structures of Tf-PEG-PE with different PEG molecular weights $\left(2,5\right.$, and $10 \mathrm{kDa}$, represented as $\mathrm{Tf}-\mathrm{PEG}_{2 \mathrm{k}}-\mathrm{PE}$, Tf-PEG ${ }_{5 \mathrm{k}}-\mathrm{PE}$, and Tf-PEG ${ }_{10 \mathrm{k}}-\mathrm{PE}$, respectively) were confirmed by infrared spectroscopy: 1) $\mathrm{Tf}_{-} \mathrm{PEG}_{2 \mathrm{k}}-\mathrm{PE}$,
3,596.1 $\mathrm{cm}^{-1}$ (-NH-, $\left.-\mathrm{OH}\right), 1,920.6 \mathrm{~cm}^{-1}(-\mathrm{C}=\mathrm{O})$; 2) Tf$\mathrm{PEG}_{5 \mathrm{k}}-\mathrm{PE}, 3,619.7 \mathrm{~cm}^{-1}(-\mathrm{NH}-,-\mathrm{OH}), 1,897.2 \mathrm{~cm}^{-1}(-\mathrm{C}=\mathrm{O})$, $1,679.8 \mathrm{~cm}^{-1}$ (-HN-CO-), 1,629.6 cm-1 (-HN-CO-); and 3) $\mathrm{Tf}-\mathrm{PEG}_{10 \mathrm{k}}-\mathrm{PE}, 3,934.1 \mathrm{~cm}^{-1}(-\mathrm{NH}-,-\mathrm{OH}), 1,836.4 \mathrm{~cm}^{-1}$ $(-\mathrm{C}=\mathrm{O}), 1,676.3 \mathrm{~cm}^{-1}(-\mathrm{HN}-\mathrm{CO}-), 1,618.1 \mathrm{~cm}^{-1}(-\mathrm{HN}-\mathrm{CO}-)$. The fact that the infrared spectroscopy of Tf-PEG $\mathrm{F}_{2 \mathrm{k}}-\mathrm{PE}$ did not show the peak of $-\mathrm{HN}-\mathrm{CO}-$ confirmed that the formation of the amide linkage had failed. Therefore, $P_{2 \mathrm{k}}$ was not suitable for the preparation of Tf-PEG-PE. Transferrin has a molecular weight of around $80 \mathrm{kDa} ;{ }^{39}$ therefore, only $\mathrm{PEG}_{5 \mathrm{k}}$ and $\mathrm{PEG}_{10 \mathrm{k}}$ were linked to Tf. $\mathrm{PEG}_{2 \mathrm{k}}$ may be too small to link onto $\mathrm{Tf}$, and the yield of Tf-PEG $\mathrm{P}_{2 \mathrm{k}}-\mathrm{PE}$ was excessively low due to reasons discussed in Kim et al. ${ }^{40}$

${ }^{1} \mathrm{H}$ NMR spectroscopy of Tf-PEG ${ }_{5 \mathrm{k}}-\mathrm{PE}$ and Tf-PEG ${ }_{10 \mathrm{k}}-\mathrm{PE}$ were similar, with slight differences of the peak for PEG protons, as follows: ${ }^{1} \mathrm{H} \mathrm{NMR}\left(\mathrm{CDCl}_{3}, 300 \mathrm{MHz}\right) \delta(\mathrm{ppm})$ : $0.87\left(\mathrm{t}, \mathrm{CH}_{3}\right), 1.11-1.95$ (m, PE protons), $2.30\left(\mathrm{t}, \mathrm{COCH}_{2}\right)$, $2.40\left(\mathrm{t}, \mathrm{COCH}_{2} \mathrm{CH}_{2}, 2 \mathrm{H}\right), 2.59\left(\mathrm{~m}, \mathrm{CH}_{2} \mathrm{~N}\right), 3.37\left(\mathrm{~s}, \mathrm{OCH}_{3}\right.$ of PEG), 3.50-3.80 (m, PEG ${ }_{5 \mathrm{k}}$ protons), 3.50-4.10 (m, $\mathrm{PEG}_{10 \mathrm{k}}$ protons), 5.71 (d, NH). Tf-PEG ${ }_{5 \mathrm{k}}-\mathrm{PE}$ and Tf-PEG ${ }_{10 \mathrm{k}}-\mathrm{PE}$ were then applied separately for the decoration of PTX-DNANLC, and the resulting Tf-modified PTX-DNA-NLC were indicated as $\mathrm{Tf}_{5 \mathrm{k}}-\mathrm{PTX}-\mathrm{DNA}-\mathrm{NLC}$ and $\mathrm{Tf}_{10 \mathrm{k}}-\mathrm{PTX}-\mathrm{DNA}-$ NLC, respectively.

\section{Particle size and zeta potential}

The PTX-DNA-NLC formulation was prepared by the microemulsion technique, and Tf-PTX-DNA-NLC was prepared by electrostatic attraction and lipophilic interaction. ${ }^{19}$ The TEM pictures of PTX-DNA-NLC, Tf $_{5 \mathrm{k}}$-PTXDNA-NLC, and $\mathrm{Tf}_{10 \mathrm{k}}$-PTX-DNA-NLC are shown in Figure 2. PTX-DNA-NLC had aspherical shape. $\mathrm{Tf}_{5 \mathrm{k}}$-PTX-DNANLC and $\mathrm{Tf}_{10 \mathrm{k}}$-PTX-DNA-NLC had slight, light coats on white, spherical-shaped particles. The particle size and zeta potential changes from blank NLC to PTX-DNA-NLC, Tf $_{5 \mathrm{k}}{ }^{-}$ PTX-DNA-NLC, and $\mathrm{Tf}_{10 \mathrm{k}}$-PTX-DNA-NLC are calculated in Figure 3. The average size of PTX-DNA-NLC was 79 $\mathrm{nm}$, almost the same as blank NLC (76 nm); no statistical difference was found $(P>0.05)$. These results could be evidence that the loading of drug and gene did not expand the size of the NLC formulation. After the decoration of Tf-PEG $_{5 \mathrm{k}}$-PE and Tf-PEG ${ }_{10 \mathrm{k}}$-PE onto the surface of PTXDNA-NLC, $\mathrm{Tf}_{5 \mathrm{k}}-\mathrm{PTX}-\mathrm{DNA}-\mathrm{NLC}$ and $\mathrm{Tf}_{10 \mathrm{k}}$-PTX-DNANLC achieved sizes of $133 \mathrm{~nm}$ and $236 \mathrm{~nm}$, respectively. Particle size can influence the distribution of nanocarriers. ${ }^{41}$ A small particle size is an advantage for NLC because it decreases uptake by the liver, prolongs circulation time in the blood, and improves bioavailability. ${ }^{42}$ Small vectors are also minimally phagocytosed by macrophages, so 

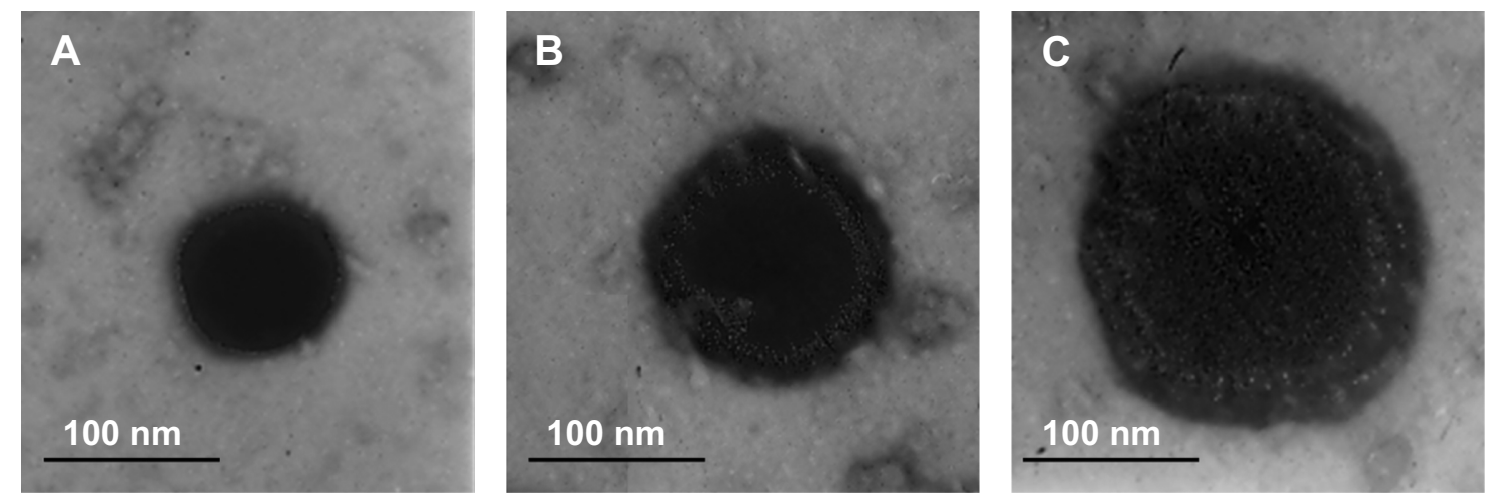

Figure 2 TEM imaging of different NLC formulations.

Notes: PTX-DNA-NLC (A) had a spherical shape. $\mathrm{Tf}_{5 \mathrm{k}}-\mathrm{PTX}$-DNA-NLC (B) and $\mathrm{Tf}_{10 \mathrm{k}}$-PTX-DNA-NLC (C) had slight, light coats on white, spherical-shaped particles. Abbreviations: NLC, nanostructured lipid carriers; TEM, transmission electron microscopy; PTX-DNA-NLC, paclitaxel- and deoxyribonucleic acid-loaded nanostructured lipid carriers; $\mathrm{Tf}_{5 \mathrm{~K}}$-PTX-DNA-NLC, transferrin-conjugated polyethylene glycol 5000-phosphatidylethanolamine-decorated paclitaxel- and deoxyribonucleic acid-loaded nanostructured lipid carriers; $\mathrm{Tf}_{10 \mathrm{k}}$-PTX-DNA-NLC, transferrin-conjugated polyethylene glycol 10000 -phosphatidylethanolamine-decorated paclitaxel- and deoxyribonucleic acid-loaded nanostructured lipid carriers.

destruction and clearance by the body is minimized. ${ }^{43}$ The size of $\mathrm{Tf}_{5 \mathrm{k}}$-PTX-DNA-NLC was significantly smaller than $\mathrm{Tf}_{10 \mathrm{k}}$-PTX-DNA-NLC $(P<0.05)$, which may cause variance in therapeutic efficiency.

The zeta potential of blank NLC was positive $(+33 \mathrm{mV})$, due to the cationic surfactant (DOTMA) used for the preparation of NLC. When PTX and DNA were loaded, the potential of PTX-DNA-NLC decreased to $+25 \mathrm{mV}$. After modification with Tf-PEG ${ }_{5 \mathrm{k}}-\mathrm{PE}$ and Tf-PEG $\mathrm{P}_{10 \mathrm{k}}-\mathrm{PE}$, zeta potential was +19 and $+8 \mathrm{mV}$, respectively. Cationic surface charge of nanocarriers can affect the internalization process. ${ }^{44}$ Cationic vectors could exploit the negative charges present at the cell surface for increased residence time and penetration. ${ }^{45}$ Nanocarriers with a higher surface charge may bind strongly to the cell membrane, and may show increased cellular uptake due to electrostatic interactions between the anionic membrane and cationic carries. ${ }^{46}$ The results of the zeta potential analysis showed the decoration of Tf-PEG-PE ligands covered some of the surface charge of the NLC, resulting in a decrease in the positive charge. The zeta potential of $\mathrm{Tf}_{5 \mathrm{k}}-\mathrm{PTX}-\mathrm{DNA}-\mathrm{NLC}$ was significantly higher than $\mathrm{Tf}_{10 \mathrm{k}}$-PTX-DNA-NLC $(P<0.05)$; this property might enhance its cellular uptake and intracellular activity.

\section{DNA-loading ability and PTX- encapsulation efficiency}

The PicoGreen fluorometry method was applied to determine the DL of different formulations. The DL of PTX-DNANLC, $\mathrm{Tf}_{5 \mathrm{k}}$-PTX-DNA-NLC, and $\mathrm{Tf}_{10 \mathrm{k}}$-PTX-DNA-NLC was $92 \%, 90 \%$, and $91 \%$, respectively, with no significant difference $(P>0.05)$ (Table 1). The DNA-binding stability of

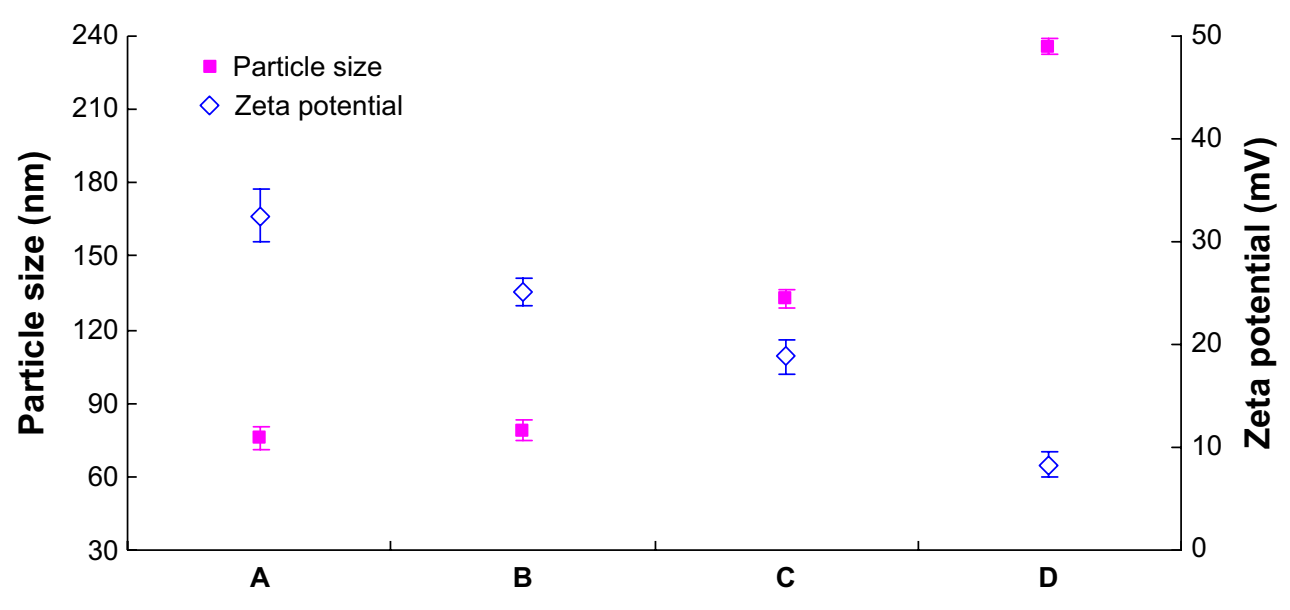

Figure 3 The particle size and zeta potential of different NLC formulations.

Notes: The particle size $(\mathrm{nm})$ and zeta potential $(\mathrm{mV})$ of $(\mathbf{A})$ blank NLC, (B) PTX-DNA-NLC, (C) Tf ${ }_{5 k}-$ PTX-DNA-NLC, and (D) Tf ${ }_{10 k}-$ PTX-DNA-NLC.

Abbreviations: NLC, nanostructured lipid carriers; Tf-PTX-DNA-NLC, transferrin-decorated paclitaxel and deoxyribonucleic acid co-encapsulated nanostructured lipid carriers; PTX-DNA-NLC, paclitaxel- and deoxyribonucleic acid-loaded nanostructured lipid carriers; Tf-PEG-PE, transferrin-conjugated polyethylene glycolphosphatidylethanolamine; $\mathrm{Tf}_{5 \mathrm{~K}}$-PTX-DNA-NLC, transferrin-conjugated polyethylene glycol 5000-phosphatidylethanolamine-decorated paclitaxel- and deoxyribonucleic acid-loaded nanostructured lipid carriers; $\mathrm{Tf}_{10 \mathrm{k}}$-PTX-DNA-NLC, transferrin-conjugated polyethylene glycol 10000 -phosphatidylethanolamine-decorated paclitaxel- and deoxyribonucleic acid-loaded nanostructured lipid carriers. 
Table I Characterization of different vectors

\begin{tabular}{llll}
\hline Vectors & PTX-DNA-NLC & Tf $_{5 \mathrm{k}}$-PTX-DNA-NLC & Tf $_{10 \mathrm{k}}$-PTX-DNA-NLC \\
\hline $\mathrm{DL}(\%)$ & $92.2 \pm 1.9$ & $90.3 \pm 1.6$ & $90.9 \pm 2.7$ \\
EE $(\%)$ & $87.1 \pm 2.1$ & $85.4 \pm 2.9$ & $82.8 \pm 3.1$ \\
\hline
\end{tabular}

Abbreviations: DL, DNA-loading ability; EE, encapsulation efficiency; PTX-DNA-NLC, paclitaxel- and deoxyribonucleic acid-loaded nanostructured lipid carriers; $\mathrm{Tf}_{5 \mathrm{~K}}$-PTXDNA-NLC, transferrin-conjugated polyethylene glycol 5000-phosphatidylethanolamine-decorated paclitaxel- and deoxyribonucleic acid-loaded nanostructured lipid carriers; $\mathrm{Tf}_{10 \mathrm{~K}}$-PTX-DNA-NLC, transferrin-conjugated polyethylene glycol 10000-phosphatidylethanolamine-decorated paclitaxel- and deoxyribonucleic acid-loaded nanostructured lipid carriers.

nanocarriers is essential for the protection of genetic material against enzymatic degradation and the production of high levels of gene expression in cellular systems ${ }^{47}$ As shown in the results, all NLC formulations obtained around $90 \%$ DL, suggesting good DNA-loading ability of NLC. In addition, Tf decoration did not affect the binding of DNA.

The EE of PTX-DNA-NLC, Tf $f_{5 \mathrm{k}}$-PTX-DNA-NLC, and $\mathrm{Tf}_{10 \mathrm{k}}$-PTX-DNA-NLC was $87 \%, 85 \%$, and $83 \%$, respectively (Table 1). Entrapment efficiency is an important parameter in the determination of drug-release characteristics; therefore, its determination is an integral part of formulation development. ${ }^{41}$ The high EE of the NLC formulations suggested that Tf-containing ligands did not detach the drug from the NLC vectors and that the modified vectors were stable.

\section{In vitro drug release}

The in vitro drug release profiles of PTX-DNA-NLC, $\mathrm{Tf}_{5 \mathrm{k}}{ }^{-}$ PTX-DNA-NLC, and $\mathrm{Tf}_{10 \mathrm{k}}$-PTX-DNA-NLC, as compared with Taxol, are illustrated in Figure 4. The release of PTX from the Taxol solution was much faster than from

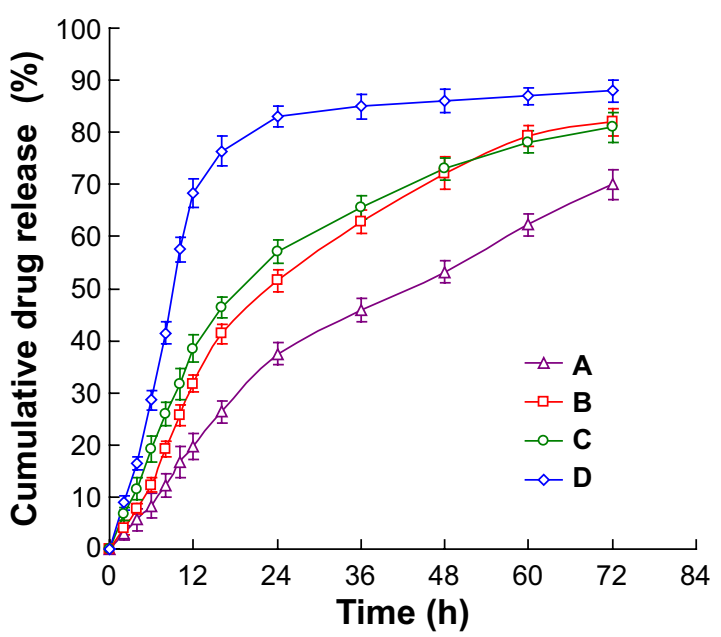

Figure 4 In vitro drug release profile of different NLC formulations. Notes: The in vitro drug release profile of $(\mathbf{A}) \mathrm{Tf}_{10 \mathrm{k}}-\mathrm{PTX}-\mathrm{DNA}-\mathrm{NLC},(\mathbf{B}) \mathrm{Tf}_{5 \mathrm{k}}-\mathrm{PTX}$ DNA-NLC, (C) PTX-DNA-NLC, and (D) Taxol ${ }^{\circledR}$.

Abbreviations: h, hours; NLC, nanostructured lipid carriers; PTX-DNA-NLC, paclitaxel- and deoxyribonucleic acid-loaded nanostructured lipid carriers; $\mathrm{Tf}_{5 \mathrm{~K}}-\mathrm{PTX}$ DNA-NLC, transferrin-conjugated polyethylene glycol 5000-phosphatidylethanolamine-decorated paclitaxel- and deoxyribonucleic acid-loaded nanostructured lipid carriers; $\mathrm{Tf}_{10 \mathrm{~K}}-\mathrm{PTX}-\mathrm{DNA}-\mathrm{NLC}$, transferrin-conjugated polyethylene glycol 10000 phosphatidylethanolamine-decorated paclitaxel- and deoxyribonucleic acid-loaded nanostructured lipid carriers.
NLC formulations, which achieved over $80 \%$ release after 24 hours. Non-Tf-decorated PTX-DNA-NLC showed a faster release during the first 24 hours, while after 24 hours until 72 hours post-introduction, it yielded almost the same release amount (82\%) as $\mathrm{Tf}_{5 \mathrm{k}}$-PTX-DNA-NLC (81\%). $\mathrm{Tf}_{10 \mathrm{k}}{ }^{-}$ PTX-DNA-NLC exhibited 70\% accumulated release during the 72 hours of test; this result may be explained by the long PEG chains that covered the surface of NLC and hindered the release of PTX. ${ }^{48,49}$ In fact, over $80 \%$ release of $\mathrm{Tf}_{10 \mathrm{k}}{ }^{-}$ PTX-DNA-NLC was observed at 96 hours. Did this release behavior help maintain sustained delivery of PTX, and did $\mathrm{Tf}_{10 \mathrm{k}}$-PTX-DNA-NLC show better antitumor efficiency? It is possible that such release behavior may, in fact, cause the reverse effect, for instance, delay drug release, which would, in turn, eliminate PTX from the organism along with the NLC vectors, thereby reducing therapeutic effect. $\mathrm{Tf}_{5 \mathrm{k}}$-PTX-DNANLC and $\mathrm{Tf}_{10 \mathrm{k}}-\mathrm{PTX}$-DNA-NLC had different drug release behavior. Which one has the better antitumor effect? The answer can be found in the "In vitro cytotoxicity" section.

\section{In vitro cytotoxicity}

Figure 5 shows the viability of NCl-H460 cells treated with different formulations. As shown in Figure 5, NLC and Tf-modified NLC without PTX showed high cell viability (around 90\%). The cytotoxic effect of nanocarriers is due to their adherence to the cell membrane, internalization, and degradation of byproducts in the cell culture medium or within cells..$^{50}$ Most lipid carriers are formulated with glycerides consisting of fatty acids, which are safe and well tolerated by organisms. ${ }^{50}$ Significant inhibitory effects of Taxol solution and NLC formulations were observed at the concentrations of $10-100 \mu \mathrm{M}$, and the toxicity conformed to a concentration-dependent pattern. Both Tf-PTX-DNA-NLC and PTX-DNA-NLC showed significantly higher cytotoxicity than PTX solution $(P<0.05)$. $\mathrm{Tf}_{5 \mathrm{k}}$-PTX-DNA-NLC had the highest cytotoxic effect among all formulations, higher than $\mathrm{Tf}_{10 \mathrm{k}}$-PTX-DNA-NLC $(P<0.05)$. The half maximal inhibitory concentration $\left(\mathrm{IC}_{50}\right)$ values of $\mathrm{Tf}_{5 \mathrm{k}}$-PTX-DNA-NLC, $\mathrm{Tf}_{10 \mathrm{k}}$-PTX-DNA-NLC, PTX-DNA-NLC, and Taxol were $3.35,7.12,7.36$, and $14.45 \mu \mathrm{M}$, respectively. The $\mathrm{IC}_{50}$ value of Tf $_{5 \mathrm{k}}$-PTX-DNA-NLC exhibited more than a four-fold dose 


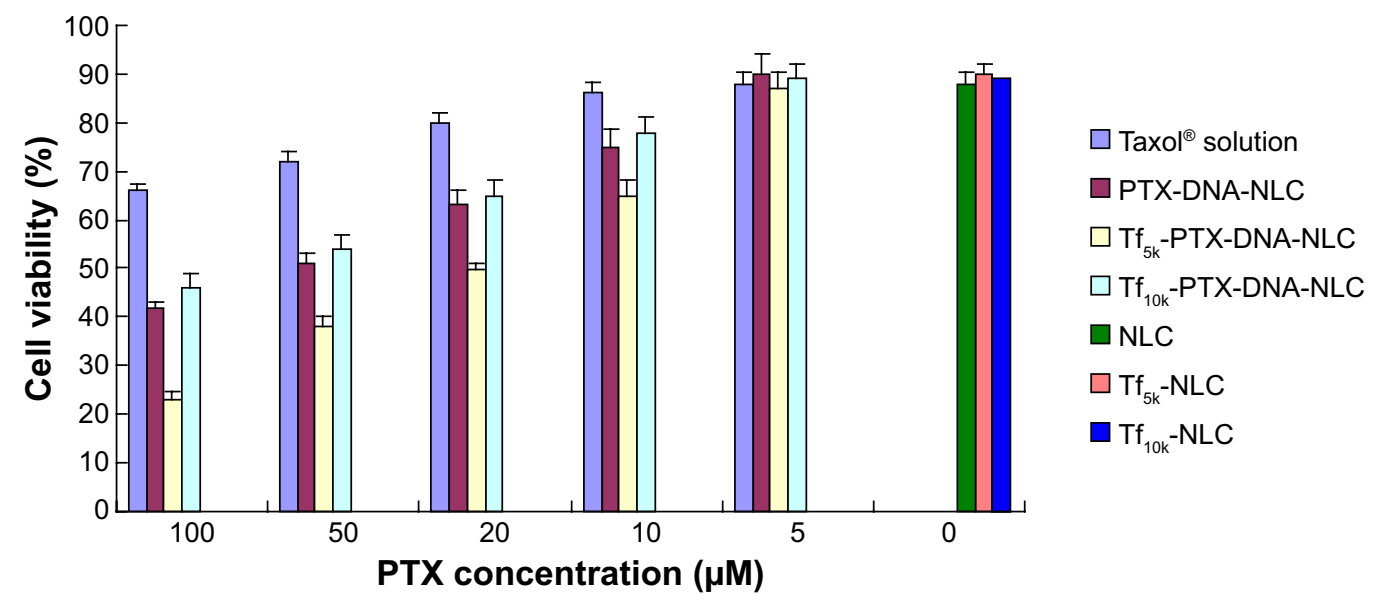

Figure 5 In vitro cytotoxicity of different NLC formulations.

Notes: Cell viability tests of $\mathrm{Taxol}^{\circledR}$, PTX-DNA-NLC, $\mathrm{Tf}_{5 \mathrm{k}}-\mathrm{PTX}-\mathrm{DNA}-\mathrm{NLC}$, and $\mathrm{Tf}_{10 \mathrm{k}}-\mathrm{PTX}-\mathrm{DNA}-\mathrm{NLC}$ were performed at the PTX concentrations of 5, $10,20,50$, and $100 \mu \mathrm{M}$. Blank NLC, blank $\mathrm{Tf}_{5 k}-\mathrm{NLC}$, and blank $\mathrm{Tf}_{10 \mathrm{k}}-\mathrm{NLC}$ were also analyzed as contrast. $\mathrm{Tf}_{5 \mathrm{k}}-\mathrm{PTX}-\mathrm{DNA}-\mathrm{NLC}$ had the highest cytotoxic effect compared with other formulations $(P<0.05)$.

Abbreviations: PTX, paclitaxel; NLC, nanostructured lipid carriers; PTX-DNA-NLC, paclitaxel- and deoxyribonucleic acid-loaded nanostructured lipid carriers; Tf -PTX- $^{-}$ DNA-NLC, transferrin-conjugated polyethylene glycol 5000-phosphatidylethanolamine-decorated paclitaxel- and deoxyribonucleic acid-loaded nanostructured lipid carriers; $\mathrm{Tf}_{10 \mathrm{k}}$-PTX-DNA-NLC, transferrin-conjugated polyethylene glycol 10000-phosphatidylethanolamine-decorated paclitaxel- and deoxyribonucleic acid-loaded nanostructured lipid carriers.

advantage over PTX solution in reducing viability of lung cancer cells, accounting for the highest antitumor activity. Also, the $\mathrm{IC}_{50}$ value of $\mathrm{Tf}_{10 \mathrm{k}}$-PTX-DNA-NLC was almost the same as non-modified PTX-DNA-NLC, and the dose was two times more than $\mathrm{Tf}_{5 \mathrm{k}}$-PTX-DNA-NLC. No advantage was shown in Tf-PEG ${ }_{10 \mathrm{k}}$-PE-decorated NLC; this result may be because relatively longer PEG chains covered the surface of NLC and blocked the release of drugs.

\section{In vivo antitumor efficacy}

The antitumor efficacy of Tf-PTX-DNA-NLC and PTX-DNANLC was assessed in NCl-H460 cell-bearing mice. As shown in Figure 6, although tumor growth was suppressed to some extent after administration of Taxol, the NLC formulations appeared to be much more potent when the mice were treated, and the tumor growth in mice was significantly inhibited $(P<0.05)$. At 14 days of treatment, tumor inhibition rates of tumor-bearing mice treated with $\mathrm{Tf}_{5 \mathrm{k}}-\mathrm{PTX}-\mathrm{DNA}-\mathrm{NLC}, \mathrm{Tf}_{10 \mathrm{k}}{ }^{-}$ PTX-DNA-NLC, and PTX-DNA-NLC were $23 \%, 51 \%$, and $42 \%$, respectively, compared with controls. $\mathrm{Tf}_{5 \mathrm{k}}$-PTX-DNANLC exhibited better tumor regression than $\mathrm{Tf}_{10 \mathrm{k}}$-PTX-DNANLC. This result is in accordance with the results of our current in vitro cytotoxicity study. Moreover, $\mathrm{Tf}_{10 \mathrm{k}}$-PTX-DNA-NLC showed no better tumor inhibition efficacy compared with PTX-DNA-NLC, which could be negative evidence for using Tf-PEG ${ }_{10 \mathrm{k}}-\mathrm{PE}$ as a ligand for decoration of NLC.

\section{In vivo and in vitro gene transfection}

The in vitro transfection efficiencies of $\mathrm{Tf}_{10 \mathrm{k}}$-PTX-DNANLC, $\mathrm{Tf}_{5 \mathrm{k}}-\mathrm{PTX}$-DNA-NLC, PTX-DNA-NLC, Lipo-DNA, and free DNA solution were evaluated in HepG2 cells after 72 hours of transfection (Figure 7). Blank NLC was used as contrast. The transfection efficiency of $\mathrm{Tf}_{5 \mathrm{k}}$-PTX-DNANLC was lower than Lipo-DNA complexes at both 36- and

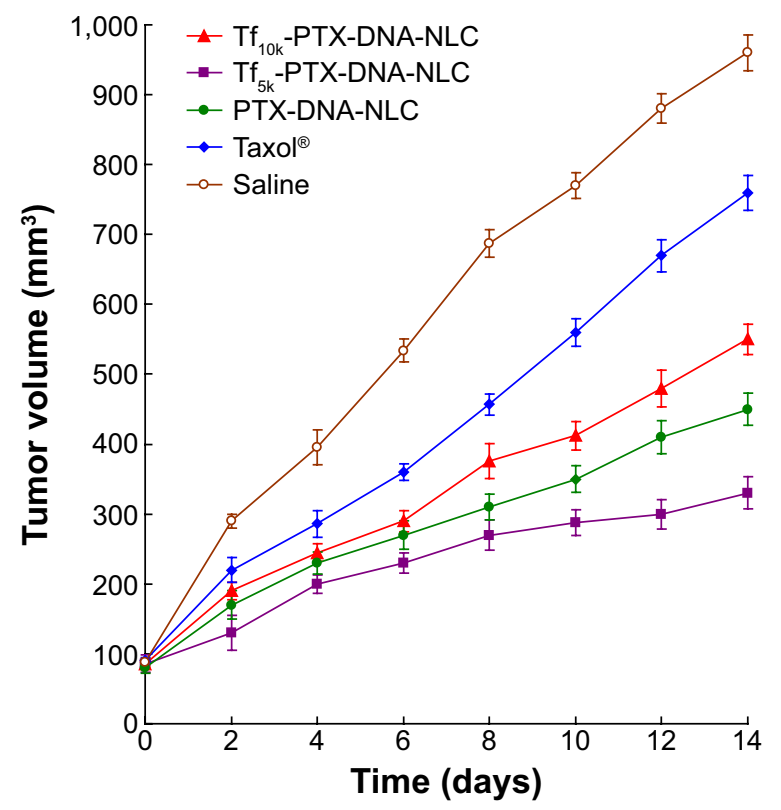

Figure 6 Effects of different NLC formulations on tumor growth in vivo. Notes: Tumor growth was suppressed to some extent after administration of $\mathrm{Taxol}^{\circledR}$. $\mathrm{Tf}_{5 \mathrm{k}}-\mathrm{PTX}-\mathrm{DNA}-\mathrm{NLC}$ exhibited significantly better tumor regression than $\mathrm{Tf}_{10 \mathrm{k}}$-PTX-DNA-NLC and PTX-DNA-NLC $(P<0.05)$.

Abbreviations: NLC, nanostructured lipid carriers; PTX-DNA-NLC, paclitaxeland deoxyribonucleic acid-loaded nanostructured lipid carriers; $\mathrm{Tf}_{5 \mathrm{k}}-\mathrm{PTX}$-DNANLC, transferrin-conjugated polyethylene glycol 5000-phosphatidylethanolaminedecorated paclitaxel- and deoxyribonucleic acid-loaded nanostructured lipid carriers; $\mathrm{Tf}_{10 \mathrm{k}}-\mathrm{PTX}-\mathrm{DNA}-\mathrm{NLC}$, transferrin-conjugated polyethylene glycol 10000 phosphatidylethanolamine-decorated paclitaxel- and deoxyribonucleic acid-loaded nanostructured lipid carriers. 


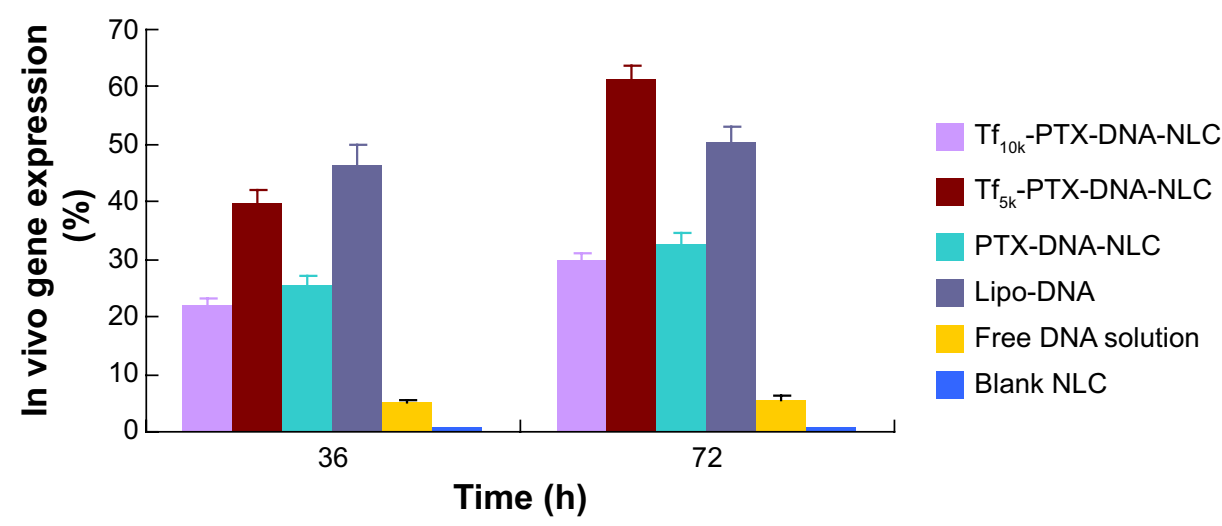

Figure 7 Flow cytometry analysis of in vitro gene transfection.

Notes: Significantly higher transfection efficiency was observed in $\mathrm{Tf}_{5 \mathrm{k}}-\mathrm{PTX}-\mathrm{DNA}-\mathrm{NLC}$ and Lipo-DNA than other formulations at both 36 hours and 72 hours after transfection $(P<0.05)$. At 36 hours, the transfection efficiency of $\mathrm{Tf}_{5 \mathrm{k}}-\mathrm{PTX}-\mathrm{DNA}-\mathrm{NLC}$ was lower than Lipo-DNA complexes $(P<0.05)$, while higher transfection efficiency was obtained at 72 hours when compared with Lipo-DNA $(P<0.05)$. Tf $10 \mathrm{k}$-PTX-DNA-NLC did not exhibit good in vitro gene transfection ability at either 36 or 72 hours. Abbreviations: h, hours; NLC, nanostructured lipid carriers; DNA, deoxyribonucleic acid; Lipo-DNA, Lipofectamine ${ }^{\circledR}$-DNA complexes; Tf ${ }_{5 k}-P{ }^{-D X-D N A-N L C, ~ t r a n s f e r r i n-~}$

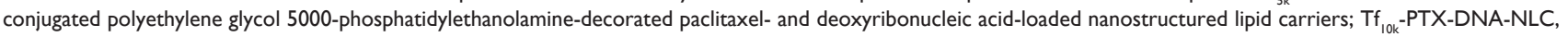
transferrin-conjugated polyethylene glycol 10000-phosphatidylethanolamine-decorated paclitaxel- and deoxyribonucleic acid-loaded nanostructured lipid carriers.

72-hours after transfection $(P<0.05)$, while higher transfection efficiency was obtained at 72 hours when compared with Lipo-DNA $(P<0.05)$. This might be because during the first period of time, DNA had a controlled-release phase from $\mathrm{Tf}_{5 \mathrm{k}}-\mathrm{PTX}$-DNA-NLC, due to the surface coating of PEG-containing ligands. At 72 hours, DNA was almost completely released from the vectors; even higher transfection efficiency was obtained. On the other hand, $\mathrm{Tf}_{10 \mathrm{k}}$-PTX-DNA-NLC did not act well in in vitro gene transfection ability at either 36 or 72 hours. To further determine the gene transfection efficacy of the vectors, in vivo experiments were carried out.

The in vivo transfection efficiencies of $\mathrm{Tf}_{10 \mathrm{k}}$-PTX-DNANLC, $\mathrm{Tf}_{5 \mathrm{k}}$-PTX-DNA-NLC, PTX-DNA-NLC, Lipo-DNA, free DNA solution, and blank NLC were evaluated in tumor-bearing BALB/c mice after 36 hours and 72 hours of transfection (Figure 8). Significantly higher transfection efficiency was observed in $\mathrm{Tf}_{5 \mathrm{k}}$-PTX-DNA-NLC and LipoDNA than other formulations at both 36 hours and 72 hours after transfection $(P<0.05)$. After transfection for 36 hours, the transfection efficiency of $\mathrm{Tf}_{5 \mathrm{k}}$-PTX-DNA-NLC was similar to that of Lipo-DNA complexes, while higher transfection efficiency was obtained at 72 hours when compared with Lipo-DNA $(P<0.05)$. This might be because during the first period of time, DNA had a controlled-release phase from $\mathrm{Tf}_{5 \mathrm{k}}$-PTX-DNA-NLC, due to the surface coating of PEG-containing ligands. At 72 hours, DNA was almost completely released from the vectors; even higher transfection efficiency was obtained. On the other hand, $\mathrm{Tf}_{10 \mathrm{k}}$-PTX-DNANLC did not act well in in vivo gene transfection ability at either 36 or 72 hours; the data were less supportive of gene transfection ability than data collected from non-decorated
PTX-DNA-NLC. It was considered from this point that PEG with a molecular weight of $10 \mathrm{kDa}$ was not suitable for transfection in this NLC system. Other researchers have reported similar results: nanoparticles can rapidly penetrate human mucus secretions if they are densely coated with low molecular weight PEG (2-5 kDa), whereas nanoparticles with $10 \mathrm{kDa}$ PEG coating were immobilized..$^{51}$ Micelles with low molecular weight PEG $(2-5 \mathrm{kDa})$ appear to be a promising carrier for drug/small interfering (si)RNA co-delivery,

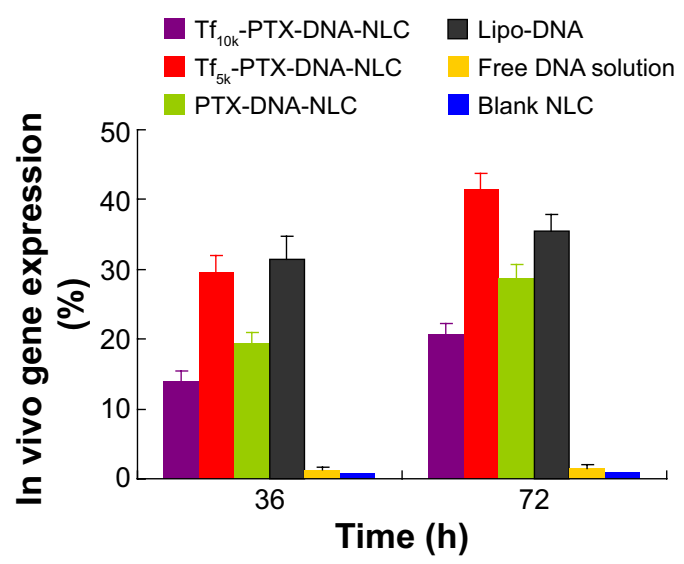

Figure 8 Flow cytometry analysis of in vivo gene transfection.

Notes: Significantly higher transfection efficiency was observed in $\mathrm{Tf}_{5 \mathrm{k}}-\mathrm{PTX}$ DNA-NLC and Lipo-DNA than other formulations at both 36 hours and 72 hours after transfection $(P<0.05)$. At 36 hours, the transfection efficiency of $\mathrm{Tf}_{5 \mathrm{k}}-\mathrm{PTX}$ DNA-NLC was similar to that of Lipo-DNA complexes, while higher transfection efficiency was obtained at 72 hours when compared with Lipo-DNA $(P<0.05)$. Tf fok $^{-}$ PTX-DNA-NLC did not exhibit good in vivo gene transfection ability at either 36 or 72 hours; the data were indicative of poorer efficiency than data obtained from non-decorated PTX-DNA-NLC.

Abbreviations: h, hours; DNA, deoxyribonucleic acid; NLC, nanostructured lipid carriers; Lipo-DNA, Lipofectamine ${ }^{\circledR}$-DNA complexes; PTX-DNA-NLC, paclitaxeland deoxyribonucleic acid-loaded nanostructured lipid carriers; $\mathrm{Tf}_{5 \mathrm{~K}}-\mathrm{PTX}$-DNA-NLC, transferrin-conjugated polyethylene glycol 5000-phosphatidylethanolamine-decorated paclitaxel- and deoxyribonucleic acid-loaded nanostructured lipid carriers; $\mathrm{Tf}_{10 \mathrm{~K}}$ - $\mathrm{PTX}$ DNA-NLC, transferrin-conjugated polyethylene glycol I0000-phosphatidylethanolaminedecorated paclitaxel- and deoxyribonucleic acid-loaded nanostructured lipid carriers. 
both especially useful for the treatment of multi-drugresistant cancers. ${ }^{52}$ Liposomes with short-chain (molecular weight $=1-3 \mathrm{kDa}$ ) PEG-phospholipid conjugates showed strong interaction of PEG-phospholipid conjugates with phospholipid. ${ }^{53}$ Finally, in the current study, PEG with the molecular weight of $5 \mathrm{kDa}$ proved to be the best choice.

\section{Conclusion}

In the present work, Tf-PTX-DNA-NLC was formulated. Kinds of PEG - with different molecular weights - were used as the linker for the $\mathrm{Tf}$ decoration. The $\mathrm{Tf}_{5 \mathrm{k}}$-PTX-DNA-NLC developed during this study proved to be significantly superior, and exhibited passive and active tumor-targeting ability. Tf-mediated targeting and NLC managed steady drug and gene loading; release profiles showed clear advantages and significantly increased in vivo gene transfection efficiency and antitumor efficacy. This novel drug and gene delivery nanomedicine offers a promising combined tumor therapy strategy for the treatment of lung cancer.

\section{Disclosure}

The authors report no conflicts of interest in this work.

\section{References}

1. Jemal A, Thun MJ, Ries LA, et al. Annual report to the nation on the tatus of cancer, 1975-2005, featuring trends in lung cancer, tobacco use, and tobacco control. J Natl Cancer Inst. 2008;100(23):1672-1694.

2. Tekade RK, Dutta T, Tyagi A, Bharti AC, Das BC, Jain NK. Surface-engineered dendrimers for dual drug delivery: a receptor up-regulation and enhanced cancer targeting strategy. J Drug Target. 2008;16(10):758-772.

3. Taratula O, Kuzmov A, Shah M, Garbuzenko OB, Minko T. Nanostructured lipid carriers as multifunctional nanomedicine platform for pulmonary co-delivery of anticancer drugs and siRNA. J Control Release. 2013;171(3):349-357.

4. Kanapathipillai M, Brock A, Ingber DE. Nanoparticle targeting of anti-cancer drugs that alter intracellular signaling or influence the tumor microenvironment. Adv Drug Deliv Rev. 2014;79C-80C:107-118.

5. $\mathrm{Hu} \mathrm{CM}$, Zhang L. Nanoparticle-based combination therapy toward overcoming drug resistance in cancer. Biochem Pharmacol. 2012; 83(8):1104-1111.

6. Byrne JD, Betancourt T, Brannon-Peppas L. Active targeting schemes for nanoparticle systems in cancer therapeutics. Adv Drug Deliv Rev. 2008;60(15):1615-1626.

7. Gandhi NS1, Tekade RK2, Chougule MB. Nanocarrier mediated delivery of siRNA/miRNA in combination with chemotherapeutic agents for cancer therapy: current progress and advances. J Control Release. 2014;194:238-256.

8. Cheng D1, Cao N, Chen J, Yu X, Shuai X. Multifunctional nanocarrier mediated co-delivery of doxorubicin and siRNA for synergistic enhancement of glioma apoptosis in rat. Biomaterials. 2012;33(4):1170-1179.

9. Doktorovova S, Souto EB, Silva AM. Nanotoxicology applied to solid lipid nanoparticles and nanostructured lipid carriers - a systematic review of in vitro data. Eur J Pharm Biopharm. 2014;87(1):1-18.

10. Ma CC, He ZY, Xia S, et al. $\alpha, \omega$-cholesterol-functionalized low molecular weight polyethylene glycol as a novel modifier of cationic liposomes for gene delivery. Int J Mol Sci. 2014;15(11):20339-20354.
11. Argenta DF, de Mattos CB, Misturini FD, et al. Factorial design applied to the optimization of lipid composition of topical antiherpetic nanoemulsions containing isoflavone genistein. Int J Nanomedicine. 2014;9:4737-4747.

12. Steelandt J, Salmon D, Gilbert E, et al. Antimicrobial nanocapsules: from new solvent-free process to in vitro efficiency. Int JNanomedicine. 2014;9:4467-4474.

13. S S, S A, Krishnamoorthy K, Rajappan M. Nanosponges: a novel class of drug delivery system - review. J Pharm Pharm Sci. 2012;15(1): 103-111.

14. Moura CC, Segundo MA, Neves JD, Reis S, Sarmento B. Co-association of methotrexate and SPIONs into anti-CD64 antibody-conjugated PLGA nanoparticles for theranostic application. Int J Nanomedicine. 2014;9:4911-4922.

15. Liu D, Zhang N. Cancer chemotherapy with lipid-based nanocarriers. Crit Rev Ther Drug Carrier Syst. 2010;27(5):371-417.

16. Selvamuthukumar S, Velmurugan R. Nanostructured lipid carriers: a potential drug carrier for cancer chemotherapy. Lipids Health Dis. 2012;11:159.

17. Zhang XG, Miao J, Dai YQ, Du YZ, Yuan H, Hu FQ. Reversal activity of nanostructured lipid carriers loading cytotoxic drug in multi-drug resistant cancer cells. Int J Pharm. 2008;361(1-2):239-244.

18. Hong $\mathrm{M}$, Zhu S, Jiang Y, et al. Novel anti-tumor strategy: PEGhydroxycamptothecin conjugate loaded transferrin-PEG-nanoparticles. J Control Release. 2010;141(1):22-29.

19. Han Y, Zhang Y, Li D, Chen Y, Sun J, Kong F. Transferrin-modified nanostructured lipid carriers as multifunctional nanomedicine for codelivery of DNA and doxorubicin. Int J Nanomedicine. 2014; 9:4107-4116.

20. Chiu RY, Tsuji T, Wang SJ, Wang J, Liu CT, Kamei DT. Improving the systemic drug delivery efficacy of nanoparticles using a transferrin variant for targeting. J Control Release. 2014;180:33-41.

21. Daniels TR, Bernabeu E, Rodríguez JA, et al. The transferrin receptor and the targeted delivery of therapeutic agents against cancer. Biochim Biophys Acta. 2012;1820(3):291-317.

22. Kakimoto S, Moriyama T, Tanabe T, Shinkai S, Nagasaki T. Dualligand effect of transferrin and transforming growth factor alpha on polyethyleneimine-mediated gene delivery. $J$ Control Release. 2007;120(3):242-249.

23. Perche F, Patel NR, Torchilin VP. Accumulation and toxicity of antibody-targeted doxorubicin-loaded PEG-PE micelles in ovarian cancer cell spheroid model. J Control Release. 2012;164(1):95-102.

24. Sawant RR, Sriraman SK, Navarro G, Biswas S, Dalvi RA, Torchilin VP. Polyethyleneimine-lipid conjugate-based $\mathrm{pH}$-sensitive micellar carrier for gene delivery. Biomaterials. 2012;33(15):3942-3951.

25. Patil YB, Swaminathan SK, Sadhukha T, Ma L, Panyam J. The use of nanoparticle-mediated targeted gene silencing and drug delivery to overcome tumor drug resistance. Biomaterials. 2010;31(2):358-365.

26. Xu Z, Zhang Z, Chen Y, Chen L, Lin L, Li Y. The characteristics and performance of a multifunctional nanoassembly system for the co-delivery of docetaxel and iSur-pDNA in a mouse hepatocellular carcinoma model. Biomaterials. 2010;31(5):916-922.

27. Wang X, Li S, Shi Y, et al. The development of site-specific drug delivery nanocarriers based on receptor mediation. J Control Release. 2014;193:139-153.

28. Arbuck SG, Christian MC, Fisherman JS, et al. Clinical development of Taxol. J Natl Cancer Inst Monogr. 1993;15:11-24.

29. Journo-Gershfeld G, Kapp D, Shamay Y, Kopeček J, David A. Hyaluronan oligomers-HPMA copolymer conjugates for targeting paclitaxel to CD44-overexpressing ovarian carcinoma. Pharm Res. 2012;29(4):1121-1133.

30. Souza LG, Silva EJ, Martins AL, et al. Development of topotecan loaded lipid nanoparticles for chemical stabilization and prolonged release. Eur J Pharm Biopharm. 2011;79(1):189-196.

31. Jiang Z, Sun C, Yin Z, et al. Comparison of two kinds of nanomedicine for targeted gene therapy: premodified or postmodified gene delivery systems. Int J Nanomedicine. 2012;7:2019-2031. 
32. Kong F, Zhou F, Ge L, Liu X, Wang Y. Mannosylated liposomes for targeted gene delivery. Int J Nanomedicine. 2012;7:1079-1089.

33. Yu W, Liu C, Liu Y, Zhang N, Xu W. Mannan-modified solid lipid nanoparticles for targeted gene delivery to alveolar macrophages. Pharm Res. 2010;27(8):1584-1596.

34. Zhang XG, Miao J, Dai YQ, Du YZ, Yuan H, Hu FQ. Reversal activity of nanostructured lipid carriers loading cytotoxic drug in multi-drug resistant cancer cells. Int J Pharm. 2008;361(1-2):239-244.

35. Yang XY, Li YX, Li M, Zhang L, Feng LX, Zhang N. Hyaluronic acidcoated nanostructured lipid carriers for targeting paclitaxel to cancer. Cancer Lett. 2013;334(2):338-345.

36. Wang Y, Ma Y, Zheng Y, et al. In vitro and in vivo anticancer activity of a novel puerarin nanosuspension against colon cancer, with high efficacy and low toxicity. Int J Pharm. 2013;441(1-2):728-735.

37. Yuan L, Liu C, Chen Y, Zhang Z, Zhou L, Qu D. Antitumor activity of tripterine via cell-penetrating peptide-coated nanostructured lipid carriers in a prostate cancer model. Int $J$ Nanomedicine. 2013;8:4339-4350.

38. Kawakami S, Harada A, Sakanaka K, et al. In vivo gene transfection via intravitreal injection of cationic liposome/plasmid DNA complexes in rabbits. Int J Pharm. 2004;278(2):255-262.

39. Bartfeld NS, Law JH. Isolation and molecular cloning of transferrin from them tobacco hornworm, Manduca sexta. Sequence similarity to the vertebrate transferrins. J Biol Chem. 1990;265(35):21684-21691.

40. Kim TH, Jo YG, Jiang HH, et al. PEG-transferrin conjugated TRAIL (TNF-related apoptosis-inducing ligand) for therapeutic tumor targeting. $J$ Control Release. 2012;162(2):422-428.

41. Rahman HS, Rasedee A, How CW, et al. Zerumbone-loaded nanostructured lipid carriers: preparation, characterization, and antileukemic effect. Int J Nanomedicine. 2013;8:2769-2781.

42. Fang YP, Lin YK, Su YH, Fang JY. Tryptanthrin-loaded nanoparticles for delivery into cultured human breast cancer cells, MCF7: the effects of solid lipid/liquid lipid ratios in the inner core. Chem Pharm Bull (Tokyo). 2011;59(2):266-271.
43. De Jong WH, Borm PJ. Drug delivery and nanoparticles: applications and hazards. Int J Nanomedicine. 2008;3(2):133-149.

44. Wang CZ, Fu YC, Jian SC, et al. Synthesis and characterization of cationic polymeric nanoparticles as simvastatin carriers for enhancing the osteogenesis of bone marrow mesenchymal stem cells. J Colloid Interface Sci. 2014;432:190-199.

45. Rabinovich-Guilatt L, Couvreur P, Lambert G, Dubernet C. Cationic vectors in ocular drug delivery. J Drug Target. 2004; 12(9-10):623-633.

46. Harush-Frenkel O, Rozentur E, Benita S, Altschuler Y. Surface charge of nanoparticles determines their endocytic and transcytotic pathway in polarized MDCK cells. Biomacromolecules. 2008;9(2):435-443.

47. Kaur R, Chitanda JM, Michel D, et al. Lysine-functionalized nanodiamonds: synthesis, physiochemical characterization, and nucleic acid binding studies. Int J Nanomedicine. 2012;7:3851-3866.

48. Huang Y, Yang T, Zhang W, et al. A novel hydrolysis-resistant lipophilic folate derivative enables stable delivery of targeted liposomes in vivo. Int J Nanomedicine. 2014;9:4581-4595.

49. Gao H, Liu J, Yang C, et al. The impact of PEGylation patterns on the in vivo biodistribution of mixed shell micelles. Int J Nanomedicine. 2013;8:4229-4246.

50. Bondì ML, Craparo EF, Giammona G, et al. Nanostructured lipid carriers-containing anticancer compounds: preparation, characterization, and cytotoxicity studies. Drug Deliv. 2007;14(2):61-77.

51. Boylan NJ, Suk JS, Lai SK, et al. Highly compacted DNA nanoparticles with low MW PEG coatings: in vitro, ex vivo and in vivo evaluation. J Control Release. 2012;157(1):72-79.

52. Biswas S, Deshpande PP, Navarro G, Dodwadkar NS, Torchilin VP. Lipid modified triblock PAMAM-based nanocarriers for siRNA drug co-delivery. Biomaterials. 2013;34(4):1289-1301.

53. Bedu-Addo FK, Huang L. Interaction of PEG-phospholipid conjugates with phospholipid: implications in liposomal drug delivery. Adv Drug Del Rev. 1995;16(2-3):235-247.
International Journal of Nanomedicine

\section{Publish your work in this journal}

The International Journal of Nanomedicine is an international, peerreviewed journal focusing on the application of nanotechnology in diagnostics, therapeutics, and drug delivery systems throughou the biomedical field. This journal is indexed on PubMed Central,

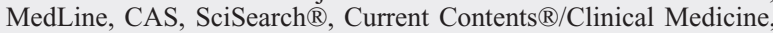

\section{Dovepress}

Journal Citation Reports/Science Edition, EMBase, Scopus and the Elsevier Bibliographic databases. The manuscript management system is completely online and includes a very quick and fair peer-review system, which is all easy to use. Visit http://www.dovepress.com/ testimonials.php to read real quotes from published authors. 